In 1915 Ghosh published his first paper on the electrolysis of solutions by alternating electric current in the Journal of the American Chemical Society. During the First World War, Snethlage (Z. phys. Chem., 90, 1, 139; 1915) published some papers criticizing the Arrhenius electrolytic dissociation theory. I pointed out the weakness of Snethlage's views (Medd. Nobel Inst., 3, No. 15; 1916), and later developed my views in a paper to the Faraday Society, and a general discussion on the present position of the theory of ionization was organized in London by the Faraday Society on January 21, 1919. In this general discussion Ghosh's contributions to the basic conception of total ionization of electrolytes wero considered and discussed and were favourably received by leading physical chemists of Britain, and papers by him were published in the Journal of the Chemical Society, London. However, other physical chemists scrutinized the conceptions and arguments of Ghosh and pointed out that they were not valid. Although Sutherland (Phil. Mag., 3, $161 ; 1902 ; 12,1 ; 1906$ ) and Milner (ibid., 25, 742; 1913 ) introduced the conception of complete ioniza. tion, Ghosh's papers were mainly responsible for the development of this idea and its applications by Debye and Hückel in their theory of strong electrolytes. Later, Ghosh and his collaborators published some interesting papers on catalytic gaseous reactions and photochemistry, which have been followed up elsewhere.

During the Second World War, Ghosh was appointed director of the Indian Institute of Science, Bangalore, which expanded in various directions during his regime. In this period he was knighted, chiefly for his war services.

When Dr. Shyama Prosad Mukherji was appointed Minister in the Union Government, he took Ghosh to Delhi to assist in the expansion of technology in India. After a short stay in Delhi, he was sent to be the first director of the Indian Tochnological Institute at Kharagpur, West Bengal. Then he was appointed the first whole-time vice-chancellor of the University of Calcutta; but he had to give up this post after a short time on his appointment as a member of the Planning Commission for Science and Technology in India.

Lady Ghosh, three sons and two daughters survive him. N. R. Dhar

\section{Prof. W. Riddet}

Prof. Winliam Riddet, director of the Dairy Research Institute (N.Z.) at Palmerston North, New Zealand, died on December 30 at the age of sixty-two.

Prof. Riddet was born of farming parents in Ayr. shire, Scotland. $\mathrm{He}$ graduated B.Sc. and N.D.A., N.D.D. (with honours) at the West of Scotland Agricultural College and the University of Glasgow. In 1921 he joined the staff of the West of Scotland Agricultural Colloge, first as dairy instructor and later as lecturer. In 1925 he migrated to New Zealand to take up the then recently established Logan Campbell ehair of agriculture at Auckland University College. In co-operation with Prof. G. S. (now Sir Geoffrey) Peren, then Walter Buchanan professor of agriculture at Victoria University College, Wellington, he organized the establishment, in 1927, of Massey Agricultural College, at Palmerston North, to which both professorships were transferred. At about the same time he played a leading part in the arrangements for the development of the Dairy Research
Institute (N.Z.), an organization set up under the agis of the N.Z. Department of Seientific and Indus. trial Research to undertake scientific research work as a service to the rapidly expanding dairy products manufacturing industry. Prof. Riddet was appointed the first director of this Institute.

Thus it was in the dual role of dean of dairying (and lator vice-principal) of Massey Agricultural College and director of the Dairy Research Institute (N.Z.) that Prof. Riddet made his outstanding contribution to the advancement of dairy science and dairy practice, and thereby to the general welfare and prosperity of his adopted country.

Prof. Riddet had from the outset that very important attribute of a leader in teaching and research, an original and ranging mind. His interests covered a wide field; and wherever his interest lay his mind was active in devising and fostering ideas for investigation and research. Endowed with what seemed to be an inexhaustible reserve of energy, he devoted himself to his duties with an astonishing persistency.

As a teacher he set for his students very exacting standards. The value of his teaching is shown in the calibre of the men who came under his influence-..they are to bo found occupying positions of high responsibility in New Zealand, in Great Britain, and in many other countries. His spirit lives in the training and inspiration he has passed on to these students.

It lives, too, in the organization which he controlled from its beginnings, the Dairy Research Institute (N.Z.). Under his guidance the Institute has gained an international reputation for its work on a number of aspects of dairying practice. While the publications describing this work do not often carry his name as author or co-author, all those who have worked under him will readily acknowledge their debt to him. With typical generosity he made no claims, and passed on his ideas without reserva. tion. It was for him sufficient recompenso that he could see the work being done and the Institute serving well the industry from which it drew its support.

The impact of Riddet's personality on the teaching of agricultural science, and on the dairy farming and dairy products manufacturing industry in New Zealand, will be evident for many years to come.

F. H. MCTOWali

\section{Mr. F. W. James}

ON January 27, Mr. Francis Wogan James, librarian to the Imperial College of Science and Technology, London, died after years of illness most bravely and eheerfully borne.

From Haverfordwest he went to the Royal College of Science as a Royal Scholar in 1930, and after taking his degree in 1933 he became a research student in inorganic chemistry. During 1936-38 he was research assistant to the professor of highway engineering in the Department of Civil Engineering of the City and Guilds College-a transfer from one to another of the constituent parts of the Imperial College which made it easy for him, in later yoars, to take a broad view of the needs of the whole College.

In 1938 'Frank' James asked the Dean of the City and Guilds College for permission to apply for the post of College librarian-an appointment which, academically and financially, was junior to the one he was holding - in order to be in a better position 
to contribute to science and learning by providing his colleagues and the students of the College with books and periodicals. How right he was the members of the College soon realized : although he never obtained a formal qualification in librarianship, he possessed a fine sense of the essentials of library service and a great love of books, and in the past twenty years the library has expanded in size much faster than the College itself and its value to the readers grew from year to year.

His work at the City and Guilds College was interrupted by war service, during 1941-46, in the Army. His work there was mainly concerned with motor transport and with radar, and his bent for these branches of engineering remained in clear evidence when he returned to his College on demobilization.

Frank James loved books, but he took an even greater interest in his readers. $\mathrm{He}$ know hundreds of students by name and the subjects on which they were working, and-being a scientist himself-knew the importance of acquainting them, as soon as a journal arrived, with papers in their fields of interest. Several new lines of research at the College were stimulated by his understanding of papers on similar subjects appearing in what seemed unlikely journals. In addition, he was, when asked, ready to offer his help in the design of apparatus and showed a fine understanding of the construction and use of chemical and electronic equipment.

$\mathrm{He}$ possessed great charm and modesty and no member of the College had a greater fund of kind- ness. Students from overseas were especially grateful to him, for he could sense the needs of shy and lonely people and give them comfort for which they, in turn, gave him their devotion. Frank James will bo sadly missed by countless friends who will long remember the kindness received from him and his charming wife. In 1958 he was appointed to be librarian in charge of all libraries at the Imporial College, and it is the College's good fortune that his spirit is alive in his staff.

$$
\text { P. O. WOLF }
$$

\section{Dr. Marcel Ballay}

DR. MARCel Batisay, president and managing director of the Centre d'Information du Nickel, Paris, died on February 2 after a short illness.

Born in 1896, Marcel Ballay entered early upon a career in metallurgy in the laboratory of the de Dion plant, of which he was afterwards appointed head, in 1925. In 1928 he joined the Centre d'Information du Nickel, first as technical manager, becoming later vice-president and in 1954 succeeding M. Jean Dhavernas as president. In 1955 he was appointed an officer of the Legion of Honour in recognition of his services to industry and to the teaching profession. He was a member of many learned societies in France and Great Britain. Under his direction the services offered to industry by the Centre d'Information du Nickel increased in importance, and it is as the head of that office and as a leading and respected metallurgist that Dr. Ballay will be remembered both in France and Great Britain.

\section{NEWS and VIEWS}

Airborne Radar at the Royal Radar Establishment: Dr. T. S. England

Dr. T. S. ENGLAND, who has been promoted to
eputy chief scientific officer and appointed head of deputy chief scientific officer and appointed head of Establishment, Malvern, graduated from the University of Durham with first-class honours in physies in 1937 and remained at Durham to undertake research on the hoating effects of ultra-short radio waves in dipole solutions. At the outbreak of the Second World War in 1939, he joined the Air Ministry Research Establishment (later the Telccommunications Research Establishment) and worked primarily on the design of radar transmitters, initially at metric and later at centimetro wave-lengths, becoming head of the 'Transmitter Design Group in 1944. He was given leave of absence from Malvern during 1948-50 to take up a research followship in medical physics at the University of Durham, when he applied his extensive knowledge of electronics to studies of the effects of microwave radiations on living tissues and of microwave resonance phenomena in paramagnetic solids and liquids. He was awarded i $\mathrm{Ph} . \mathrm{D}$. for his thesis on these researches. On return to the Telecommunications Research Establishment, Dr. England was for a time responsible for research techniques in the millimetre band before being appointed a superintendent of the Radar Ballistics Division at the Royal Radar Establishment in 1956.
Defence Research Policy Staff :

Mr. R. V. Whelpton

Mr. R. V. Whelpton, who has been promoted to deputy chief scientific officer and appointed Ministry of Supply representative on the Defence Research Policy Staff at the Ministry of Defence, took his M.Sc. at the University of Sheffield in 1938. After graduating in physies, he spent the next eight years with the research department of the MetropolitanVickers Electrical Company, where he worked on high-voltage research and on the development of the high-speed cathode-ray oscillograph. He was also engaged on investigations of transient phenomena in switchgear and the development of the eloctron microscope. In 1936 he joined Sir Robert WatsonWatt's original team on research and development of ground radar at Orfordness and Bawdsey. This work in 1940 was transferred to the Royal Aircraft Establishment at Farnborough, where Mr. Whelpton was also concerned with other aspects of radio research and development. In 1949 he continued on the same work with the Directorate of Electronics Research and Development at headquarters of the Ministry of Supply. In 1955 he was appointed scientific adviser on air defence to Supreme Headquarters Allied Powers in Europe (SHAPE) and was a member of the study group which led to the formation of the SHAPE Air Defence Technical Centre (SADTC) in The Hague. While at The Hague, as senior British representative, Mr. Whelpton pioneered efforts to 